\title{
TRERF1 Gene
}

National Cancer Institute

\section{Source}

National Cancer Institute. TRERF1 Gene. NCI Thesaurus. Code C20769.

This gene is involved in tumorigenesis. 